\title{
Images of Chinese American women on Screen: Femme Fatale and Chinese Swordswoman as the Oriental drug for Western viewers
}

\author{
Neha Tripathi \\ Research Scholar \\ University of Lucknow \\ Email id- n.tripathi121@gmail.com
}

\begin{abstract}
Representation in the U.S. film industry since the early twentieth century has invariably presented Asian women as sexualized and vampish. The figure of the Asian American femme fatale signifies a particular deathly seduction. She attracts with her soft, unthreatening and servile femininity while concealing her hard, dangerous, and domineering nature. Early images, particularly the performances of Anna May Wong, continue to this day to haunt the production and reception of Asian women on screens, such as in the star-making roles of Nancy Kwan in the 1960s and Lucy Liu in the present. If Asian/ American women's subjection is fundamentally dependent on sex, creating the parameters for Asian women's presences in popular film and in history, racialized sexuality on screen must then be sites where bondage of representation is itself re-imagined, recast and criticized at the very moment of performance... This gender imbalance not only sustains the construction of Asian American women as more desirable candidates to be assimilated when paired with White men but also reinforces the "ownership" of White American males over the bodies and spirits of Asian/American women by negating the potential physical and sexual threat imposed by Asian/American men...
\end{abstract}

Keywords- Asian American, Anna May Wong, Chinese American, Femme Fatale, Sexism, Representation

\footnotetext{
(CPerception Publishing House, 2021. This Open Access article is published under a Creative Commons Attribution NonCommercial 4.0 International License https://creativecommons.org/licenses/by-nc/4.0/, which permits non-commercial reuse, distribution, and reproduction in any medium, provided the original work is properly cited. For citation use the DOI. For commercial re-use, please contact editor @ email:- thecreativelauncher@gmail.com
} 
Representation in the U.S. film industry since the early twentieth century has invariably presented Asian women as sexualized and vampish. The figure of the Asian American femme fatale signifies a particular deathly seduction. She attracts with her soft, unthreatening and servile femininity while concealing her hard, dangerous, and domineering nature. Early images, particularly the performances of Anna May Wong, who was the first Asian American superstar of Hollywood, continue to this day to haunt the production and reception of Asian women on screens, such as in the star-making roles of Nancy Kwan in the 1960s and Lucy Liu in the present. If Asian/ American women's subjection is fundamentally dependent on sex, creating the parameters for Asian women's presences in popular film and in history, racialized sexuality on screen must then be sites where bondage of representation is itself re-imagined, recast and criticized at the very moment of performance.

The Asian actresses regard their hypersexual roles as a triangulation that challenges our two-dimensional understandings of cinematic roles for Asian women. The figures for hypersexuality are not simply found on screen but are wide intertextual and multidimensional within the characters, actresses and women who in playing them, belong to particular historical, social and cultural contexts. To see the triangulation-the multidimensional figures-is to see the site of a collision between concrete conditions and fantasies, all created within a relationship of production. These figures of fantasy rely on the visible facticity of the Asian actresses so that they themselves must engage in the popular definition of racialized sexuality as perverse. They do so in differing but resistant ways- for their varying resistances characterize the ultimately unknowable and vastly rich quality of hypersexual representations.

The Asian/ American woman in Hollywood cinema is bound to sexuality as essential to any imaginings about her as well as her actual appearances in popular culture. From the general Orientalized roles played by Anna May Wong to the detailed specificity of the "Half Chinese, half Japanese" O-Ren Ishii played by Lucy Liu in Quentin Tarantino's popular Kill Bill in Hollywood. The particular sexual subjection for the Asian woman occurs at two levels. First, the Asian femme fatale's sexual subjection in the film involves inherently different sexuality essentialized to race and culture. That is, her sexuality is ascribed as natural to her particular race and gendered ontology. Second, the Asian femme fatale's sexuality is framed in a rivalry with a 
white woman, in terms of competing for heterosexual femininity. The Asian woman's racial visibility works against the white woman's domestic or tameable gender and sexuality.

The Asian woman is an absent/present, dead/living subject on-screen upon whose body race, sex, and gender in colonial narratives are kept open with possibilities for various interpretations. The platforms and performances of Nancy Kwan in The World of Suzie Wong and Flower Drum Song and Lucy Liu today in Payback, Play it to the Bone, Charlie's Angels and Kill Bill are haunted by the performances and presences of Anna May Wong. The life and work of Anna May Wong exemplify the ethical "burden of representation" actors and actresses of colour continue to contend within their work. The Asian actresses share a response to the co-existing desire for Asian women's hypersexual visual representation to involve the possibility of verifying real Asian women- and the fear that it already does. Commenting on the publicity around her movies, Anna May Wong "speaks" about the attribution of exotic background to provide grounds for verifying her fictional roles.

After The Thief of Baghdad, the press begins to call me the 'celestial maiden'. They call me 'sloe-eyed'. They call me 'exotic'. They call me the 'Oriental siren', the 'China Doll', the 'Lotus Girl', the 'Chinese Flapper'. They call me the 'Queen of the B-films'. They say I've never cut my hair, never eaten lobster, never been on a bicycle, never owned a radio. They say I have the longest nails in Hollywood. (Anna May Wong)

As Anna says this she also captures the projection of group racial characteristics on her individual body. She is placed within freakish subjectivity-outside modernity as one untouched by technology or unaffected by cosmopolitanism. She is constructed instead as primarily racially different-that is, race organizes what subjectivity and what roles/characters are available for her.

The analysis of American popular and critical film reviews of the Chinese swordswoman suggests that she is not read from an Asian centred or an Asian specific lens that understands her as metaphors for the community she represents, but from a fabricated structure that struggles to make sense of the physical strength of the gendered "foreign" woman. This imaginative structure features localized knowledge of Hollywood conventions on strong, beautiful women with a yearning to make allegorical links to contemporary China. Sometimes "forgetting" that the Chinese female fighter is a transnational figure, American critics cling to the familiar in their decoding of the Chinese swordswoman, thus revealing the difficulties they encounter when 
engaging with texts that present nuanced representations of transnational Chinese communities such as the Chinese diaspora in America. These critics, in other words, read the Chinese swordswoman from an Orientalist lens where the Chinese woman is positioned as powerless in the historical East-West relationship. Postcolonial theorist Edward Said notes that Orientalism takes place when the West interprets the East on the West's terms. In other words, Chinese American culture and people are interpreted within American notions of what it thinks and envisions Chinese America to be. This envisioning is often romanticized where the beauty of Chinese culture, geography, and people are emphasized.

While studying and analyzing, American film reviews of the Chinese swordswoman seem dire in their recognition of transnational themes focusing on Chinese America, hope springs in the ever-growing number of popular press critics who possess informed and scholarly knowledge of cinemas other than Hollywood. Leading international expert in film studies David Bordwell is an exemplary film commentator who writes for scholarly publications as well as for the general audience. Bordwell writes prolifically about Chinese-language cinema, particularly Hong Kong cinema. It is with expectation and anticipation that a more complex framework incorporating the various tenets connected to transnational Chinese productions will be constructed. Doing so will provide more nuanced observations on transnational communities such as Chinese America when decoding multifaceted pan-Asian/Hollywood films.

Reading the Chinese swordswoman within the context of a Chinese America as a transnational community indicates certain attempts to understanding Chinese American issues and concerns. Such sentiments reveal maturity and evolution in racial and ethnic relations in multicultural America and have become one of the most visible ethnic communities in America through birth and recent immigration trends. Many American-born Chinese can trace their ethnic lineage back to the 1840 s when numerous émigrés from China entered America as cheap labourers working on railroad construction and in the gold mines. Since then ethnic Chinese from China and elsewhere have been attracted to America for a variety of economic, social and political reasons. Permanent and temporary migrants from China, together with American-born Chinese, have become integral members of American society, involving themselves in such diverse areas as the local community, business, academia, politics and entertainment. 
The hypersexual Asian/American woman in representation lives through different generations, providing vocabulary for the social cognition of Asian women. She lives as a historical subject that affects different politics and struggles in a relationship between the real and the represented as interdependent: somewhere between life and death, present and absent. There is an immense political power to this ambiguity of representation in history. Only by an admission of the Asian/ American woman as Oriental sexual phantasm can her status as sexual be rewritten as politically significant. Her subject position in representation is a diagnosis of the repression of possibilities for the Asian woman. Revisiting her sexual emblem is required so as to make dents in the problem of race, sexuality and representation within the silence of history. To rename the narratives of Asian/ American women is to identify the worlds behind the production indicated by their performances. Let us call back the dragon lady and the murderous vamp so as to initiate different conversations with the Asian/ American woman's image: to retell the stories in which she appears; to see how these stories come to speak of the excesses of the historical, the logical, and improbable. To call back the ambivalent parts of the stereotype is to make other parts of its appearance more visible and to call for a different future from its legacy. To call on the past so as to carve a different future, we need to advocate for framing film as an ancestral legacy: to ask how Asian/ American actresses are sexual heirs who rewrite hypersexuality in various ways. The Asian woman's hypersexuality needs to be reclaimed, for she is fetishized in the sense that her presence as sexual would never be allowed to actually disappear. She is kept hovering, causing anxiety and dread on the edge of absence and presence. The commoditization of Asian culture has lent itself to the marginalization of Asian American women. Lynn Lu notes that current values on "international cosmopolitanism" have transformed cultural traits into marketable goods, placing "our bodies and images even more squarely in the public domain, [making] us readily available to anyone, [rendering] us accessible for any use, while diverting attention from the deeper, often harsh realities." This co-opting of Asian American female images serves the interests of maintaining White male hegemony, upheld by patriarchy and a distinct racial hierarchy. The creation of an Other, in the case of Asian American women, has rationalized rape, sex slavery, and other forms of colonial sexual exploitation. Sunny Woan, in her "White Sexual Imperialism: A Theory on Asian Feminist Jurisprudence," points out that the dominance of a White heterosexual male presence in the 
historical interaction between America and Asian countries is the source of major cultural misconceptions and colonial misogyny. The legacy of American imperialism and sexism created the "hyper-sexualized Asian woman," who catered to a flattering and self-serving image of White males and enjoyed sexual submission. Rape and sexual domination was a tool of war, and although different, sex tourism today is arguably a similar result of imperialist attitudes justifying the exploitation of economically disadvantaged groups. The media has done little to correct or change the image of Asian women as pornographic fetish, mail-order bride, geisha, and teenage schoolgirl.

Notably, Asian/American males make rare appearances in media and other social advertisements, if we examine as compared with their female counterparts, which intimates to the racial and gender dynamics of advertisement cultures. And this is not an unprecedented trend. Following the popularity of Connie Chung, Asian American women anchorpersons have been very visible, whereas Asian American men anchors are nearly completely absent. (Espiritu 1997) This gender imbalance not only sustains the construction of Asian American women as more desirable candidates to be assimilated when paired with White men but also reinforces the "ownership" of White American males over the bodies and spirits of Asian/American women by negating the potential physical and sexual threat imposed by Asian/American men.

An Asian lady was talking to me... and all of a sudden she said to me:

"Do you know that because of Suzie Wong you made a bad impression for a lot of Asian American women?" I said, "What are you trying to say?" So she said, "You know, because Suzie Wong was a prostitute a lot of Americans got the wrong idea and they thought that all Asian women were prostitutes." I said, "I don't have any problems with the movie and I don't know why you bring this up because it's up to you and how you feel about yourself. It's only a role and it happened to be a very successful film and I'm sure that you feel that way. -Nancy Kwan

How do we evaluate the political possibilities of performances by Asian/ American actresses in Hollywood who are caught in a specific bind of hypersexual representation at different moments in history? Within two years in the early twentieth century, two separate films featuring Anna May Wong inaugurated what have since become the defining poles organizing Asian/American womanhood on screen and scene; the lotus flower and dragon lady archetypes. 
Even the lotus blossom is s a femme fatale figure in killing herself and threatening to overwhelm the white man with her devotion and loyalty. Toll of the Sea (1922) presents Anna May Wong in her first starring role as a pathologically devoted Chinese "wife" of an American husband who disavows her love. The film established Anna May Wong's talent in Hollywood with the introduction of an Asian American woman playing the character of "Lotus Flower", the selfsacrificing, servile and suicidal Asian woman, a role so compelling it continues to bind contemporary Asian/ American women on screen and scene. On the other end of the spectrum, opposing the abject, self-abnegating Asian woman is the dragon lady-also embodied by Anna May Wong in the classic film The Thief of Baghdad (1924). Wong playing a Mongol slave girl, a minor role that initiates a major trope of the Asian woman: the dragon lady whose excessively dangerous sexuality is a major emblem of her race and gender visibility. The dragon lady uses her "Oriental" femininity, associated with seduction and danger, to trap white men on behalf of conniving Asian males. The publicity materials for the film show her in an elaborate headdress that creates the effect of a large dragon shadowing her. Her contorted body mimics the dragon's shadow and her revealing ensemble of net-like silver threads show off most of her skin. Sexuality, animality, and eroticism come together in selling this body. The image of Anna May Wong shows the Asian-woman-as-dragon-lady as a sublime object of beauty hiding a grotesque interior.

The Westernized version of Orientalism reified by the advertisements and popular media serves to commodify Asian culture. Westerners' indulgence in Asian culture has been often understood as a signifier of their wealth and the broadened purview of their ability to consume (Marchetti 1993, p. 27). The consumption of Asian culture has never required an accurate comprehension of Asian cultures and histories and empathy with Third World experiences of colonialism, imperialism, and economic exploitation. The diverse ways in which Asian/American women are sexually objectified, culturally misrepresented and visually consumed by contemporary American Orientalist viewer, needs to be shattered with more significant representation of Asian American women. They need to be seen and accepted beyond their hypersexualized image and castration of their femme fatale character. What we need is to believe that Asian American women as and beyond their gender are just another woman who is doubly marginalized first by her gender and then by her race in an alien land. And if we may 
extend a little, it would do great good to offer her some kindness and love in return. To shatter the generations of stereotype is a long arduous journey but one we must start to begin, at least in this twenty-first century.

\section{Works Cited}

Bolante Antony. (2006). The slanted screen: Resources: A chronology of Asian American historical events and the films and television broadcasts that accompanied them. Retrieved Dec. 5, 2012 from http://www.slantedscreen.com/print/chronology.pdf

Bordwell, David. Eds. Noel Carroll. Post-Theory: Reconstructing Film Studies. Madison: University of Wisconsin Press: 1996.

Cimino, Michael. (Director). Year of the dragon. (Film). MGM \& Laurentiis Entertainment Group.1985.

Espiritu, Y. L. Asian American Women and Men: Labor, Laws, and love. Thousand Oaks, CA: Sage.1997.

Friedman, D. Lester. (Ed.). Unspeakable Images, Ethnicity and the American cinema (p.278). Chicago; University of Illinois Press.1991.

Hodges, Graham Russell Gao. In Anna May Wong: From Laundryman's Daughter to Hollywood Legend, 251-64. Aberdeen, Hong Kong: Hong Kong University Press, 2012.

Kang, L. H. The desiring of Asian female bodies: Interracial romance and cinematic subjection. Visual Anthropology Review, 9, 5-21. 1993.

Liu, Cynthia. When dragon ladies die, do they come back as butterflies? Countervisions Asian American film criticism(pp.23-39). Philadelphia: Temple University Press.2000.

Lu, Lynn. "Critical Visions: The Representation and Resistance of Asian Women." Dragon ladies: Asian American feminists breathe fire. Ed. Sonia Shah. Boston: South End Press, 1997.

Moy, James. (Ed.). Marginal sights: Staging the Chinese in America. Iowa City: University of Iowa Press.1993.

Marchetti, Gina. Romance and the "yellow peril": Race, sex and discursive strategies in Hollywood fiction. Berkeley, London: University of California Press, 1993.

McG. (Director). Charlie's angels. (Film). Columbia Pictures. 2000. 
Moy, James. (Ed.). (1993) Marginal Sights: Staging the Chinese in America. Iowa City: University of Iowa Press.

Quine, Richard. (Director). The world of Suzie Wong. (Film). Paramount Pictures. 1960.

Said, E. W. Orientalism. New York: Vintage. 1979.

Sakamoto, Edward. Anna May Wong and the dragon-lady syndrome. Los Angeles Times. (July 12). Los Angeles. 1987.

Taylor, C. R.,\&Stern, B. B. Asian-Americans: Television advertising and the 'model minority' stereotype. Journal of Advertising, 26, 47-31. 1997.

Woan, Sunny. "White Sexual Imperialism: A Theory of Asian Feminist Jurisprudence." Washington and Lee Journal of Civil Rights and Social Justice Law, Vol. 13. 2008. Social Science Research Network. Sandor Teszler Library. 8 August 2010.

Xing, Jun. Hybrid cinema by Asian American women. Countervisions - Asian American film criticism(pp.186-202). Philadelphia: Temple University Press. 2000. 